\title{
RESPONSE OF SAKHA 109 RICE CULTIVAR TO IRRIGATION INTERVALS AND PHOSPHORUS LEVELS
}

\author{
Hasnaa A. Ghazy, Mariam T. Wissa and I. A. Sheta \\ Rice Research and department, Field Crops Research Institute, Agricultural Research \\ Center, Egypt. *Correspondence: hasnaa.rrtc@gmail.com
}

Received: Nov. 11, 2021

Accepted: Nov. 27, 2021

\begin{abstract}
Field experiments were carried out at The Experimental Farm of Sakha Research Station, Sakha, Kafr El-Sheikh, Egypt during 2020 and 2021 seasons. The study aimed to investigate the response of Sakha 109 to irrigation intervals and phosphorus levels. A strip-plot design, with three plant replications, was used. The vertical plots contained four irrigation intervals, namely: continuous flooding (CF), irrigation every 6, 9, and 12 days (D). The horizontal plots consisted of four triple superphosphate fertilizer rates as follows: Control, 24, 48 and $72 \mathrm{~kg} \mathrm{P}_{2} \mathrm{O}_{5} / \mathrm{ha}$. The results revealed that Leaf area index (LAl), dry matter $/ \mathrm{m}^{2}$, plant height, number of panicles $/ \mathrm{m}^{2}$, number of filled grains/panicle, panicle length, panicle weight, 1000 grain weight and grain yield significantly increased at CF and 6D, 9D, as compared to the 12D treatment. Leaf area index, dry matter, plant height, grain yield, and its components were increased significantly by the application of 48 and $72 \mathrm{~kg} \mathrm{P}_{2} \mathrm{O}_{5} /$ ha without significant differences between the two treatments. Continuous flooding consumed the highest amount of total applied water while, the lowest amount was exerted by irrigation every 12 days. Irrigation every 6 days gave a similar grain yield to that of CF with less amount of irrigation water and gave reasonable water productivity in both seasons. Generally, it is suitable to use irrigation every 6 days with the application of $48 \mathrm{~kg} \mathrm{P}_{2} \mathrm{O}_{5} / \mathrm{ha}$ for the highest grain yield of Sakha 109 and best water productivity.
\end{abstract}

Key words: Rice, Irrigation intervals, phosphorus, water productivity, grain yield.

\section{INTRODUCTION}

Water scarcity is one of the abiotic restrictions that has a global impact on agricultural productivity. Drought stress is thought to be capable of reducing crop production by roughly $20 \%$ over the world. (Subramanian, 2008). In addition, water deficit conditions affect the crop growth and grain yield (Wu et al., 2009). Rice (Oryza sativa L.) is the world's second-largest primary food crop, behind wheat, and one of Egypt's most important staple crops. It is not only their basic food crop, but also a major source of energy in their daily diet. Rice is a semi-aquatic crop that thrives in damp soil; therefore its production technique requires a lot of water. Rice may be grown in a variety of ecological circumstances depending on the availability of water. However, irrigation resources have steadily reduced over the last few decades, resulting in a water scarcity situation. (Huang et al., 2007). Prolonging irrigation interval reduces absorption of nutrients and photosynthesis, causing reduction in number of tiller, leaf surface, LAl and redistribution of dry matter production. Thus, rice grain yield and its attributes were reduced (El-Refaee et al., 2021).

Phosphorus, after nitrogen ( $\mathrm{N})$, is the second most important element in terms of agricultural productivity. It is a nonrenewable natural resource, and there is rising worry over phosphorus fertilizer shortages in natural deposits of rock phosphate. (Vinod and Heuer., 2012). According to estimates, $50 \%$ of agricultural soils are lacking in P. (Lynch 2011). The two primary reasons are insufficient phosphorus delivery in the 
Hasnaa A. Ghazy, et al.,

form of phosphorus fertilizer or manure, and P-fixing soil properties, which render phosphorus unavailable to plants even when considerable amounts are present.

As a result of phosphorus nutrition is a limiting factor in terms of achieving economic yield (Guimarães et al., 2018). Low soil phosphate is a serious constraint on plant growth and productivity in numerous crops around the world, including rice. To overcome phosphorus deficit, extra phosphorus fertilizers are applied (Roy et al., 2021). A lack of accessible phosphorus causes a reduction in rice grain yield by lowering tiller number, dry matter accumulation, distribution, and leaf photosynthetic capacity. Photosynthesis, flowering, seed generation, maturity, and root expansion are just a few of the processes in which it is involved. Its absence can result in severe stunting and yield losses. (Okasha., 2020). Because $P$ is usually found in the insoluble form of tricalcium phosphate, it is more necessary to regulate it (Aziz et al, 2006).

The objective of the present study is to examine the interactions between irrigation intervals and phosphorus levels and their effects on water and grain yield productivity of Sakha 109 rice cultivar.

\section{MATERIALS AND METHODS}

Two field experiments were conducted at the Experimental Farm of Sakha Research Station, Sakha, Kafr El-Sheikh, Egypt during 2020 and 2021 seasons. The purpose was to investigate effect of the irrigation treatments and phosphorus levels on growth, grain yield, and water productivity of Sakha 109 rice cultivar. All experiments were preceded by barley (Hordum vulgare). The results of mechanical and chemical soil properties are presented in Table (1).

The experiments were laid out in a strip-plot design, with three replications. The verticsl plots were devoted to four irrigation treatments, as follows.
1. Continuous flooding (CF) throughout the seasons,

2. Irrigation every 6 days (6D),

3. Irrigation every 9 days (6D)

4. Irrigation every 12 days (12D).

The horizontal plots were assigned to four phosphorus fertilizer treatments as follows: control, 24, 48, and $72 \mathrm{~kg} \mathrm{P}_{2} \mathrm{O}_{5} /$ ha as a basal application to the soil during the land preparation (calcium super-phosphate). The nursery was well plowed and leveled. Fertilizer treatments and the rest cultural practices were applied as recommended to the nursery. Seeds of Sakha 109 rice cultivar, at the rate of $144 \mathrm{~kg} \mathrm{ha}^{-1}$ were soaked in sufficient water for 24 hours and incubated for another 48 hours to enhance germination. Pre-germinated seeds were broadcasted in the presence of water after puddling the nursery on the $8^{\text {th }}$ and $10^{\text {th }}$ of May in the first and second season, respectively. Potassium fertilizer was added at $57 \mathrm{~kg} \mathrm{~K}_{2} \mathrm{O} \mathrm{ha}{ }^{-1}$ as a basal dose and incorporated into dry soil. According to the treatments, the recommended dose of nitrogen fertilizer form of urea $72 \mathrm{~kg} \mathrm{~N} / \mathrm{ha}$ was applied. The plots size was of $30 \mathrm{~m}^{2}(5 \times 6 \mathrm{~m})$ each. All plots were transplanted with three to four thirty-day-old seedlings at $20 \mathrm{~cm}$ distance among hills and rows. To avoid lateral irrigation water movement and for more water control, each main plot was lightly separated by two-meter-wide ditches. At the booting stage (75 days from sowing), plants from five hills were randomly taken from each subplot to estimate dry matter production and leaf area index (LAI). At harvest, plant height was estimated. The total number of panicles of ten random hills was counted and then converted into numbers $/ \mathrm{m}^{2}$. Ten random panicles were collected from each plot to estimate panicle length, number of grains/panicle, unfilled grain percentage, panicle weight, and 1000grain weight. Grain yields were randomly measured from an inert area of $12 \mathrm{~m}^{2}(3 \mathrm{x}$ $4 \mathrm{~m}$ ), and grain yield was adjusted to $14 \%$ moisture content. 
Table (1): Mechanical and chemical analysis of the experimental site soil.

\begin{tabular}{ccccccccc}
\hline $\begin{array}{c}\text { Soil } \\
\text { analysis }\end{array}$ & $\begin{array}{c}\text { Texture } \\
\text { class }\end{array}$ & pH & $\begin{array}{c}\text { EC } \\
\text { dS/m }\end{array}$ & $\begin{array}{c}\text { Organic } \\
\text { matter \% }\end{array}$ & $\begin{array}{c}\text { Total N } \\
\text { ppm }\end{array}$ & $\begin{array}{c}\text { Available } \\
\text { P ppm }\end{array}$ & $\begin{array}{c}\text { Available } \\
\text { K ppm }\end{array}$ & $\begin{array}{c}\text { Available } \\
\text { Zn ppm }\end{array}$ \\
\hline 2020 & clayey & 7.8 & 1.73 & 1.70 & 480 & 14 & 288 & 1.14 \\
\hline 2021 & clayey & 8.0 & 2.37 & 1.60 & 487 & 13 & 267 & 1.15 \\
\hline
\end{tabular}

\section{The total applied water:}

A water pump provided with a calibrated water meter, was used for all water measurements. The weight of grain yield per unit of water ( $\mathrm{kg}$ grain $/ \mathrm{m}^{3}$ water) was used to calculate water productivity.

\section{Statistical Analysis}

The data was examined statistically using the analysis of variance technique, according to Gomez and Gomez (1984). The treatment means were compared using Duncan's Multiple Range Test (Duncan 1955). Using the "COSTAT" statistical software tool, all statistical analyses were completed using the analysis of variance technique.

\section{RESULTS AND DISCUSSION}

\section{1-Growth attributes:}

The values of leaf area index were high in continuous flooding (CF) without any significant differences with irrigation every 6 days compared to irrigation every 12 days (Table 2). Prolonging irrigation intervals from CF up to irrigation every 12 days reduced LAl, dry matter (DM) and plant height. The dry matter production and tallest plants were obtained when the plants were irrigated as continuous flooding in two seasons. Phosphorus rates significantly influenced the growth characteristics compared with control treatment (Table 2). The maximum values of studied traits (LAI, DM, and plant height) were significantly increased by increasing phosphorus fertilizer rate and were noted in plants treated with $72 \mathrm{~kg} /$ $\mathrm{P}_{2} \mathrm{O}_{5} /$ ha without significant differences from those produced by $48 \mathrm{~kg} / \mathrm{P}_{2} \mathrm{O}_{5} /$ ha as compared to control treatment in both seasons.

Results in Table 3 showed that the interaction between phosphorus fertilizer and irrigation treatments on dry matter production were significant in the 2020 and 2021 seasons. The highest dry matter production values were obtained by combining $\mathrm{CF}$ treatment with the treatment of 72 and $48 \mathrm{~kg} \mathrm{P}_{2} \mathrm{O}_{5} /$ ha without any significant difference between the above mentioned combinations. However, treatment of control (without phosphorus) under irrigation every 12 days produced the minimum values of dry matter in both seasons.

\section{2- Grain yield and its attributes:}

The data in Table 4 showed that the CF irrigation significantly produced the maximum values of all grain yield and its attributes (number of panicles $/ \mathrm{m}^{2}$, number of filled grains/panicle, panicle length, panicle weight, 1000 grain weight, and grain yield/ ha) in both seasons, with no significant difference with a 6-day interval. On the other hand, irrigation every 12days gave the minimum values of all traits, except for the number of unfilled grains in both seasons. The treatment of $72 \mathrm{~kg} \mathrm{P}_{2} \mathrm{O}_{5} / \mathrm{ha}$ recorded the highest values of all grain yield attributes without any significant differences with those obtained by $48 \mathrm{~kg} \mathrm{P}_{2} \mathrm{O}_{5} /$ ha treatment. Meanwhile, the control treatment (without phosphorus) exerted the minimum values of such traits in both seasons (Table 4), except for the number of unfilled grains, which was the highest value under the control treatment in both 
Hasnaa A. Ghazy, et al.,

seasons. Data presented in Table 4 indicated that all grain yield and its attributes were significantly increased by increasing the phosphorus fertilizer rates. The treatment of $72 \mathrm{~kg} \mathrm{P}_{2} \mathrm{O}_{5} / \mathrm{ha}$ recorded the highest values of all grain yield attributes without any significant differences with those obtained by the 48 $\mathrm{kg}_{2} \mathrm{O}_{5} /$ ha treatment. Meanwhile, control induced the minimum values of such traits in both seasons (Table 4), except the number of unfilled grains, which was highest under control in both seasons.

Table 2: Some growth characteristic of rice at harvest as affected by irrigation intervals and phosphorus fertilizer rates.

\begin{tabular}{|c|c|c|c|c|c|c|}
\hline \multirow{2}{*}{ Treatments } & \multicolumn{2}{|c|}{ LAI } & \multicolumn{2}{|c|}{ Dry matter $\left(\mathrm{g} / \mathrm{m}^{2}\right)$} & \multicolumn{2}{|c|}{ Plant height (cm) } \\
\hline & 2020 & 2021 & 2020 & 2021 & 2020 & 2021 \\
\hline \multicolumn{7}{|c|}{ Irrigation intervals (I): } \\
\hline CF & $5.05 a$ & $5.33 a$ & $1031.00 a$ & $1120.00 a$ & $100.39 a$ & $101.25 a$ \\
\hline 6-day & $4.85 \mathrm{a}$ & $5.01 \mathrm{a}$ & $987.08 b$ & $1011.00 b$ & $97.29 b$ & $98.99 b$ \\
\hline 9-day & $3.61 \mathrm{~b}$ & $4.24 b$ & $830.17 \mathrm{c}$ & $943.00 \mathrm{c}$ & $88.05 c$ & $92.39 c$ \\
\hline 12-day & $3.28 b$ & $3.34 \mathrm{c}$ & 641.99d & $805.99 d$ & $72.41 d$ & $77.68 d$ \\
\hline F. test & ** & ** & ** & ** & ** & ** \\
\hline \multicolumn{7}{|c|}{ Phosphorus rates $\mathrm{kg} \mathrm{P}_{2} \mathrm{O}_{5} / \mathrm{ha}(\mathrm{P})$} \\
\hline control & $3.86 \mathrm{c}$ & 4.14c & $856.90 d$ & 954.34d & $88.16 \mathrm{c}$ & $91.95 c$ \\
\hline 24 & $4.12 b$ & $4.40 \mathrm{~b}$ & $872.03 c$ & $966.47 \mathrm{c}$ & $88.57 b$ & $92.36 b$ \\
\hline 48 & 4.33ab & $4.61 \mathrm{ab}$ & $878.42 b$ & 975.86b & $89.06 a$ & $92.86 a$ \\
\hline 72 & $4.47 a$ & $4.75 a$ & $885.88 a$ & $983.32 \mathrm{a}$ & $89.36 a$ & $93.15 a$ \\
\hline F. test & ** & ** & ** & ** & ** & ** \\
\hline \multicolumn{7}{|l|}{ Interaction } \\
\hline I X P & NS & NS & * & * & NS & NS \\
\hline
\end{tabular}

${ }^{*}=$ Significant at 0.05 level, ${ }^{\star \star}=$ Significant at 0.01 level and NS= not significant.. CF= continuous flooding

Table 3: Dry matter $\left(\mathrm{g} / \mathrm{m}^{2}\right)$ of Sakha 109 rice cultivar as affected by the interaction between irrigation intervals and phosphorus fertilizer rates during 2020 and 2021 seasons

\begin{tabular}{|c|c|c|c|c|c|c|c|c|}
\hline \multirow{4}{*}{$\begin{array}{l}\text { Phosphorus } \\
\left.\text { (kg } \mathrm{P}_{2} \mathrm{O}_{5} / \mathrm{ha}\right)\end{array}$} & \multicolumn{8}{|c|}{ Dry matter $\left(\mathrm{g} / \mathrm{m}^{2}\right)$} \\
\hline & \multicolumn{4}{|c|}{2020} & \multicolumn{4}{|c|}{2021} \\
\hline & \multicolumn{8}{|c|}{ Irrigation treatments } \\
\hline & CF & 6-day & 9-day & 12-day & CF & 6-day & 9-day & 12-day \\
\hline Control & $1017.9 \mathrm{c}$ & $971.4 f$ & $804.8 j$ & $633.6 \mathrm{~m}$ & $486.9 c$ & 995.3j & 917.6j & $797.6 m$ \\
\hline 24 & $1027 b$ & $985.3 e$ & $826.2 i$ & $637.8 \mathrm{Im}$ & $1115.9 b$ & $1009.2 e$ & 939.0h & $801.8 \mathrm{Im}$ \\
\hline 48 & $1035.9 a$ & 992.9de & $840.4 \mathrm{~h}$ & $644.6 \mathrm{kl}$ & $1124.9 a$ & $1017 \mathrm{de}$ & $953.2 \mathrm{~h}$ & $808.6 \mathrm{kl}$ \\
\hline 72 & 1043.3a & 998.8d & $849.3 \mathrm{~g}$ & $652.1 \mathrm{k}$ & $1132.3 a$ & $1022.7 d$ & $962.2 \mathrm{~g}$ & 816.0k \\
\hline
\end{tabular}

CF= continuous flooding. 


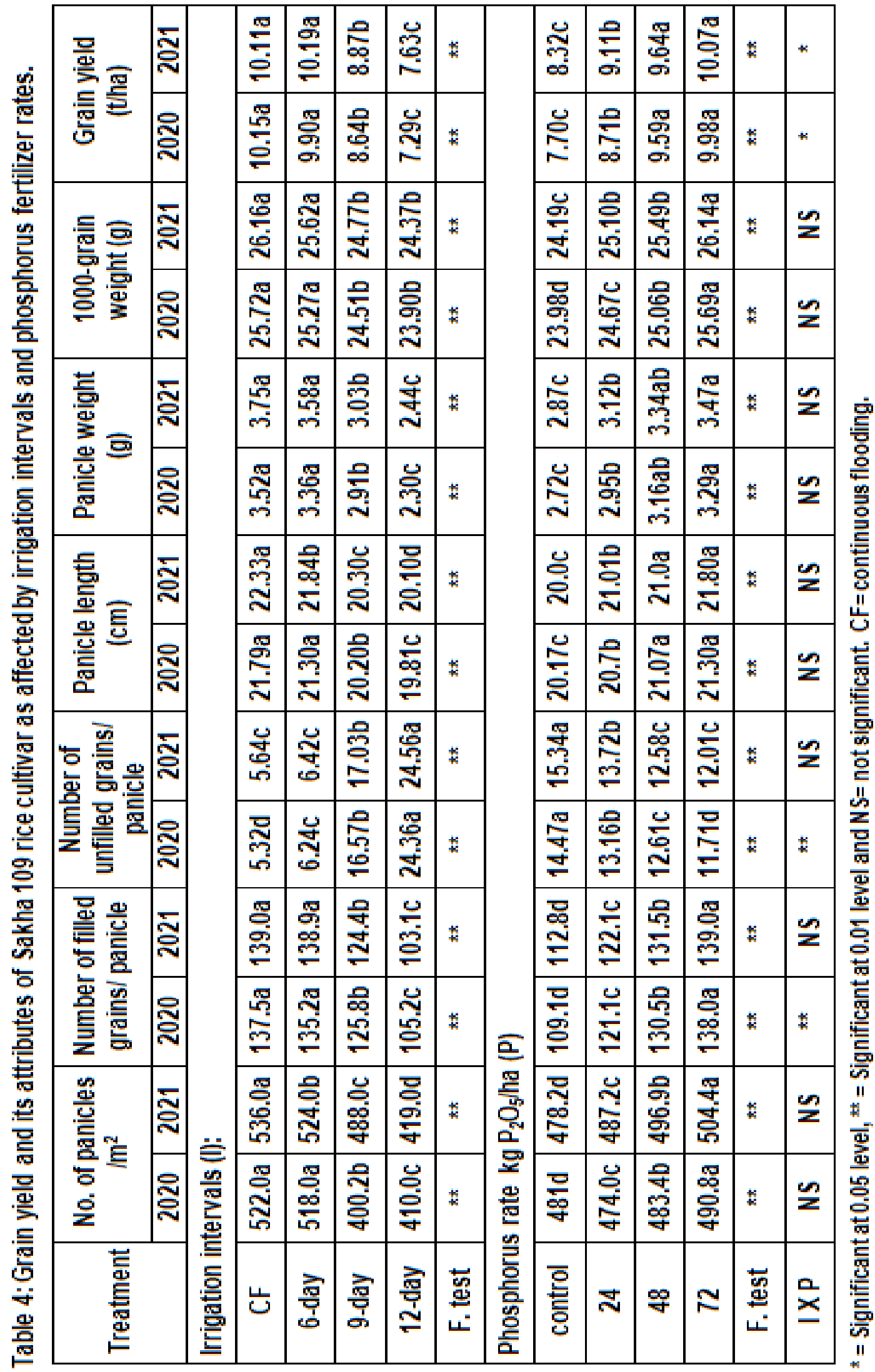


Hasnaa A. Ghazy, et al.,

The interaction between irrigation intervals and phosphorus fertilizer rates was significant for the number of filled grains/ panicle and number of unfilled grains/ panicles in the first season (Table 5). The highest number of filled grains/ panicles was produced in continuous flooding and the treatment of $72 \mathrm{~kg} \mathrm{P}_{2} \mathrm{O}_{5} /$ ha combination without any significant difference between the irrigation every 6 days with treatment of $48 \mathrm{~kg} \mathrm{P}_{2} \mathrm{O}_{5} /$ ha in 2020 season. On the other hand, the lowest value of number of filled grains/ panicles was produced in irrigation every 12days with control (without phosphorus). The interaction between Irrigation intervals and phosphorus fertilizer rates was significant for the number of unfilled grains/ panicle in the 2020 season (Table 5). The highest number of unfilled grains/ panicle was produced by the combination of irrigation every 12 days combined with no phosphorus. While, the lowest value was produced by CF with the treatment of 72 kg $\mathrm{P}_{2} \mathrm{O}_{5} /$ ha treatment in 2020 season. The interaction between irrigation regimes and phosphorus fertilizer rate was significant for grain yield in both seasons (Table 5). The highest grain yield was obtained by and treatment of 72 and $48 \mathrm{~kg} \mathrm{P}_{2} \mathrm{O}_{5} /$ ha under continuous flooding followed by irrigation every 6 days treatment, without any significant difference between each other. However, the lowest value was produced by irrigation every 12 days with control (without applied as phosphorus) treatment in both seasons.

Table 5: Number of filled, number of unfilled grain/ panicle and grain yield of Sakha 109 rice cultivar as affected by the interaction between irrigation intervals and phosphorus fertilizer rates.

\begin{tabular}{|c|c|c|c|c|c|c|c|c|}
\hline \multirow{3}{*}{$\begin{array}{c}\text { Phosphorous } \\
\mathrm{kgP}_{2} \mathrm{O}_{5} / \text { ha }\end{array}$} & \multicolumn{4}{|c|}{ Number of filled grains/ panicle } & \multicolumn{4}{|c|}{ Number of unfilled grain/ panicle } \\
\hline & \multicolumn{4}{|c|}{2020} & \multicolumn{4}{|c|}{2020} \\
\hline & CF & 6-day & 9-day & 12-day & CF & 6-day & 9-day & 12-day \\
\hline control & 124.4de & $119.5 \mathrm{e}$ & $100.4 \mathrm{gh}$ & $91.8 \mathrm{~h}$ & $5.98 \mathrm{gh}$ & $6.85 \mathrm{~g}$ & $18.91 d$ & $26.14 c$ \\
\hline 24 & $133.4 \mathrm{~cd}$ & $133.4 \mathrm{~cd}$ & $121.8 \mathrm{e}$ & $96.0 \mathrm{gh}$ & $5.58 \mathrm{gh}$ & $6.68 \mathrm{~g}$ & $17.24 \mathrm{e}$ & 24.97c \\
\hline 48 & 142.4abc & $141.0 \mathrm{ab}$ & $136.0 \mathrm{bc}$ & $102.8 \mathrm{fg}$ & $5.27 \mathrm{gh}$ & $6.09 \mathrm{~g}$ & $15.37 f$ & $24.70 b$ \\
\hline 72 & $149.8 \mathrm{a}$ & $147.0 \mathrm{ab}$ & $145.0 \mathrm{abc}$ & $48.3 f$ & $4.44 \mathrm{~h}$ & $5.33 \mathrm{gh}$ & $14.47 f$ & $22.63 a$ \\
\hline \multirow{3}{*}{$\begin{array}{c}\text { Phosphorous } \\
\mathrm{kgP}_{2} \mathrm{O}_{5} / \text { ha }\end{array}$} & \multicolumn{8}{|c|}{ Grain yield(t/ha) } \\
\hline & \multicolumn{4}{|c|}{2020} & \multicolumn{4}{|c|}{2021} \\
\hline & CF & 6-day & 9-day & 12-day & CF & 6-day & 9-day & 12-day \\
\hline control & $8.82 \mathrm{fg}$ & $8.43 \mathrm{fgh}$ & $7.74 \mathrm{~h}$ & $5.81 \mathrm{j}$ & 9.44de & 8.89 efg & $8.10 \mathrm{gh}$ & $6.86 i$ \\
\hline 24 & $10.0 \mathrm{bcd}$ & $9.85 \mathrm{cde}$ & $8.05 \mathrm{gh}$ & $6.90 \mathrm{i}$ & $10.57 \mathrm{abc}$ & 10.1bcd & 8.50fgh & $7.27 i$ \\
\hline 48 & 10.16ab & 10.51abc & $9.18 \mathrm{ef}$ & $7.98 \mathrm{gh}$ & 10.78ab & $10.74 a b$ & 9.01 ef & $8.02 \mathrm{~h}$ \\
\hline 72 & $11.08 \mathrm{a}$ & 10.82ab & 9.58de & 8.47fgh & $11.04 a$ & $11.01 a$ & $9.8 \mathrm{~cd}$ & 8.37fgh \\
\hline
\end{tabular}




\section{3- Total applied water, water saved and water productivity}

Data in Table 6 revealed that the total water used, water saved and water productivity was significantly influenced by the irrigation intervals in both seasons. The treatment CF consumed the highest amounts of water throughout the seasons. While the lowest amounts were used by irrigation every 12 days treatment in both seasons. The amount of water-saving percentage was found to be 8.84 and $10.51 \%$ with irrigation every 6 days treatment in the first and second season, respectively. At the same time, the water-saving percentage under irrigation every 9 days was 13.59 and $12.18 \%$ with prolonged irrigation interval followed by irrigation every 12 days treatment (31.33 and $30.13 \%)$ compared with continuous flooding in the 2020 and 2021 seasons, respectively. The irrigation every 6 days recorded the highest value of water productivity $(0.872$ and 0.911 $\mathrm{kg} / \mathrm{m}^{3}$ ) followed by irrigation every 12 days in the first and second seasons, respectively. In these treatments, the irrigation every 6 days treatment resulted in high grain yields with low water inputs.

Table 7 showed that the effect of the irrigation intervals and phosphorus fertilizer rates on water productivity. Water productivity increased with irrigation every 12 days with the $72 \mathrm{~kg}$ $\mathrm{P}_{2} \mathrm{O}_{5} /$ ha treatment in the first and second season.

Table 6: Total applied water, water saved and water productivity as affected by irrigation treatments

\begin{tabular}{|c|c|c|c|c|c|c|}
\hline \multirow{2}{*}{$\begin{array}{c}\text { Irrigation } \\
\text { treatment }\end{array}$} & \multicolumn{2}{|c|}{$\begin{array}{c}\text { Total water use } \\
\left(\mathrm{m}^{3} / \mathrm{ha}\right)\end{array}$} & \multicolumn{2}{c|}{ Water saved (\%) } & \multicolumn{2}{c|}{$\begin{array}{c}\text { Water productivity } \\
\left(\mathrm{kg} / \mathrm{m}^{3}\right)\end{array}$} \\
\cline { 2 - 7 } & 2020 & 2021 & 2020 & 2021 & 2020 & 2021 \\
\hline CF & 12447 & 12147 & - & - & 0.815 & 0.832 \\
\hline 6- day & 11347 & 11181 & 8.84 & 7.95 & 0.872 & 0.911 \\
\hline 9-day & 10756 & 10668 & 13.59 & 12.18 & 0.803 & 0.831 \\
\hline 12-day & 8547 & 8487 & 31.33 & 30.13 & 0.853 & 0.899 \\
\hline
\end{tabular}

CF= continuous flooding

Table 7: Water productivity $\left(\mathrm{kg} / \mathrm{m}^{3}\right)$ affected by the interaction between irrigation intervals and phosphorus fertilizer rates.

\begin{tabular}{|c|c|c|c|c|c|c|c|c|}
\hline \multirow{3}{*}{$\begin{array}{l}\text { Phosphorus } \\
\mathrm{kgP}_{2} \mathrm{O}_{5} / \mathrm{ha}\end{array}$} & \multicolumn{8}{|c|}{ Irrigation intervals } \\
\hline & \multicolumn{4}{|c|}{2020} & \multicolumn{4}{|c|}{2021} \\
\hline & CF & 6-day & 9-day & 12-day & CF & 6-day & 9-day & 12-day \\
\hline control & 0.709 & 0.743 & 0.720 & 0.680 & 0.777 & 0.795 & 0.759 & 0.808 \\
\hline 24 & 0.803 & 0.868 & 0.748 & 0.807 & 0.870 & 0.903 & 0.797 & 0.857 \\
\hline 48 & 0.816 & 0.926 & 0.853 & 0.934 & 0.887 & 0.961 & 0.845 & 0.945 \\
\hline 72 & 0.890 & 0.954 & 0.891 & 0.991 & 0.909 & 0.985 & 0.919 & 0.986 \\
\hline
\end{tabular}

$\mathrm{CF}=$ continuous flooding 


\section{DISCUSSION}

Prolonging irrigation intervals from continuous flooding up to irrigation every 12 days reduced LAI, DM, and plant height. The increase in water availability may increase root growth, high mobility of nutrients in soil solution, and nutrient absorption by plant roots that stimulate the physiological processes inside the plant, such as protein synthesis and photosynthesis. In contrast, prolonged irrigation intervals during early stages of tiller development inhibits the activities of many enzymes, leading to adverse changes in the structures of plant tissues (Alhassan et al., 2016, Hameed et al., 2019, Hossain et al., 2020 and El-Refaee et al., 2021). Phosphorus fertilizers improve vigorous growth superficial roots, increase growth, photosynthesis and its partitioning, delay leaf senescence under stress, enhance synthesis of RNA, and enhance the efficiency of photochemistry and ATP compound in rice plant leading to higher yield components (Zayed et al., 2010).

Plants treated with $72 \mathrm{~kg} / \mathrm{P}_{2} \mathrm{O}_{5} / \mathrm{ha}$ had the highest values of the examined variables (LAI, DM, and plant height). Both root and shoot development might be attributed to a lack of phosphorus. Increased $P$ levels boost plant growth metrics by increasing leaf photosynthetic rate and synthesis of extra photosynthates (Rahman et al., 2011). The involvement of phosphorus in rice plant growth and development, as well as an increase in the number of tillers and root development, could explain the rise in LAl as P levels rise. (Khan et al., 2016).

The highest values of all grain yield attributes (number of panicles $/ \mathrm{m}^{2}$, number of filled grains / panicle, panicle length, panicle weight, 1000 grain weight, and grain yield) were obtained by CF without significant difference with a 6day interval compared to irrigation every 12 days. The available water enhanced the production and transportation of the dry matter content to panicles for new tillers. As a result, the number of tillers increased, as did the overall number of grains/panicles. Continuous flooding had the highest panicle weight and grain yield, without a significant difference with irrigation every 6 days. A lack of water shortens the grain-filling period, and it can lead to a decrease in grain weight. Similar findings have been reported by Pandey et al. (2014). Also, such results might be interpreted by the increase in soil moisture content during the vegetative growth of rice plants, which affects the activity of cell division and elongation, and improved physiological processes inside the plant such as photosynthesis, enzyme activity and transportation of the dry matter content to panicles. According to Li et al. (2017) and Hossain et al., (2020), high grain yield resulted in more grain filling and weighted panicles. Higher yield and yield attributes, as well as a higher net economic return, are the ideal combination. Other researchers found that a good combination of $P$ and irrigation increased the number of panicles per $\mathrm{m}^{2}$. (Usman, 2013). Because of the closer watering intervals, the interactions between phosphorus fertilizer rate and irrigation intervals had a beneficial effect on yield attributes. Shorter irrigation intervals maintained a moderate moisture content in the soil, which improved grain fullness and panicle weight by increasing cytokinin levels, which increased grain output. (Zhang et al, 2010). This could be related to better root formation and growth, which leads to better moisture management and higher crop yields (He, 2010). Water stress impairs agricultural plants' capacity to develop and photosynthesize by upsetting the equilibrium between reactive oxygen species and antioxidant defenses, resulting in an excess of reactive oxygen species that induce oxidative stress to proteins, membrane lipids, and other 
cellular components. Water stress has an impact on the photochemical and enzymatic activity of crop plants. As a result of the stress, paddy yields are decreasing. Higher phosphorus paddy yields are most likely due to more panicles and bigger biomass, which result in higher rice yields. (George and colleagues, 2001). These findings imply that water productivity rises to a point in response to phosphorus levels, then falls. Irrigation intervals are negatively associated with water productivity, implying that as water production declines with longer irrigation intervals. When there is a scarcity of water, phosphorus plays a critical function in increasing water productivity. (Zayed et al., 2017) cited that apply phosphorus to rice crop grown under stress enables it to uptake water in spite of high osmotic pressure.

An appropriate phosphorus level is not only useful for saving water, but it's also a good way to increase paddy production. This could be related to greater root growth and development, which leads to increased crop yields and better moisture utilization (He, 2010). Water productivity and paddy yield are both reduced by excessive irrigation water use (Tao et al. 2006). In general, panicle phosphorous fertilizer increased water production when used in conjunction with the appropriate irrigation level, owing to high yield and minimal seepage and percolation losses. (Pandey et al. 2014 and Gewaily et al. 2019).

\section{CONCLUSION}

The study indicates that the phosphorus fertilizer rates of $48 \mathrm{~kg} \mathrm{P}_{2} \mathrm{O}_{5} /$ ha in combination with irrigation every 6 days could be the most effective for enhancing the highest grain yield and acceptable water productivity of the Sakha 109 rice cultivar.

\section{REFERENCES}

Alhassan, I., A.M. Saddiq, A. Ibrahim and Y. Mustapha (2016). Effects of Irrigation Frequency and Nitrogen Fertilizer Application on Yield and Water Use Efficiency of Lowland Rice (Oryza sativa L.) in Northeastern Nigeria. Mayfeb Journal of Agricultural Science, 4: 20-27.

Aziz, T., M.A. Rahmatullah, M.A. Maqsood, I.A. Tahir and M.A. Cheema (2006). Phosphorus utilization by six Brassica cultivars (Brassica juncea L.) from tri-calcium phosphate; a relatively insoluble $\mathbf{P}$ compound. Pakistan Journal of Botany, 38(5): 1529-1538.

Duncan, D.B. (1955). Multiple range and multiple F tests. Biometrics, 11(1): 142.

El-Refaee, I.S., Hasnaa A. Ghazy and I. A. Sheta (2021). Effect of nitrogen fertilizer splitting and water management on productivity and grain quality of Giza 179 rice cultivar. Menoufia Journal of Plant Production, 6 (10): $465-477$.

George, T., R. Magbanua, W. Roder, K. Van Keer, G. Trébuil and V. Reoma (2001). Upland rice response to phosphorus fertilization in Asia. Agronomy Journal, 93(6): 1362-1370.

Gewaily, E.E., A.T. Mohammed and W.T. Abd El-Rahem (2019). Effect of different irrigation treatments on productivity and cooking quality of some rice varieties. World Journal of Agricultural Sciences, 15(5):341-354.

Gomez, K.A. and A.A. Gomez (1984). Statistical procedures for agricultural research. John Wiley and Sons.

Guimarães, C.M., L.F. Stone, M.D.C.S. Carvalho and J.M. Colombari (2018). Performance of low phosphorus tolerant rice genotypes under drought stress. Revista Ceres, 65: 253-260.

Hameed, F., J. Xu, S.F. Rahim, Q. Wei, R. Khalil and Q. Liao (2019). Optimizing nitrogen options for improving nitrogen use efficiency of rice under 
Hasnaa A. Ghazy, et al.,

different water treatments. Agronomy, 9(1): 39.

He, C. (2010). Effects of furrow irrigation on the growth, production, and water use efficiency of direct sowing rice. The Scientific World Journal, 10: 14831497.

Hossain, M.Z., S. Sikder, A. Husna, S. Sultana, S. Akhter, A. Alim and J.C. Joardar (2020). Influence of Water Stress on Morphology, Physiology and Yield Contributing Characteristics of Rice. SAARC Journal of Agriculture, 18(1): 61-71.

Huang, Y., B. Xiao and L. Xiong (2007). Characterization of a stress responsive proteinase inhibitor gene with positive effect in improving drought resistance in rice. Planta, 226(1):73-85.

Khan, S.U.T., A. Iqbal and S. Fahad (2016). Growth and productivity response of hybrid rice to application of animal manures, plant residues and phosphorus. Frontiers in plant science, 7: 1440.

Li, T., O. Angeles, M. Marcaida, E. Manalo, M.P. Manalili, A. Radanielson and S. Mohanty (2017). From ORYZA2000 to ORYZA (v3): An improved simulation model for rice in drought and nitrogen-deficient environments. Agricultural and forest meteorology, 247: 248-256.

Lynch, J.P. (2011). Root phenes for enhanced soil exploration and phosphorus acquisition: tools for future crops. Plant physiology, 156(3): 1041-1049.

Okasha, A. (2020). The role of activated phosphorous sources in enhancing soil quality and rice productivity under saline sodic soil conditions. ,Doi: 10.21608/asajs.2020.119553. 8 (3) : 81107.

Pandey, P.K., P.H. Kass, M.L. Soupir, S. Biswas and V.P. Singh (2014). Contamination of water resources by pathogenic bacteria. Amb Express, 4(1): 1-16.

Rahman, K. M. M., M. A. K. Chowdhury, F. Sharmeen, A. Sarkar, M. A. Hye and G.
C. Biswas (2011). Effect of zinc and phosphorus on yield of Oryza sativa. Bangladesh Research. Publication of Bangladeshi journals 5: 351-358.

Roy, S., B.C. Verma, A. Banerjee, J. Kumar, U.S. Ray and N.P. Mandal (2021). Genetic diversity for drought and low-phosphorus tolerance in rice (Oryza sativa L.) varieties and donors adapted to rain fed drought-prone ecologies. Scientific Reports, 11(1): 19.

Subramanian, D. (2008). Water Deficit Condition Affecting Rice ProductionChallenges and Prospects. Crop Production Technologies, 6: 1-24.

Tao, H., H. Brueck, K. Dittert, C. Kreye, S. Lin and B. Sattelmacher (2006). Growth and yield formation of rice (Oryza sativa L.) in the water-saving ground cover rice production system (GCRPS). Field Crops Research, 95(1): 1-12.

Usman, K. (2013). Effect of phosphorus and irrigation levels on yield, water productivity, phosphorus use efficiency and income of lowland rice in northwest Pakistan. Rice Science, 20(1): 61-72.

Vinod, K.K. and S. Heuer (2012). Approaches towards nitrogen-and phosphorus - efficient rice. AoB Plants,10(31) doi; 10.1093/aobpla/ pls028.

Wu, X., Y. Shiroto, S. I. Y. Kishitani and K. Toriyama (2009). Enhanced heat and drought tolerance in transgenic rice seedlings overexpressing OsWRKY11 under the control of HSP101 promoter. Plant Cell Reports, 28(1): 21-30.

Zayed, B., M. Abdelaal and G. Deweedar (2017). Response of rice yield and soil to sulfur application under water and salinity stresses. Egyptian Journal of Agronomy, 39(3): 239-249.

Zhang, H., T. Chen, Z. Wang, J. Yang and J. Zhang (2010). Involvement of cytokinins in the grain filling of rice under alternate wetting and drying irrigation. Journal of Experimental Botany, 61(13): 3719-3733. 
استجابة صنف الأرز سخا 109 لفترات الري ومستويات من التسميد الفوسفورى

حناء عبد الحميد غازي، مريم طلعت ويصا، ابراهيم على شتا

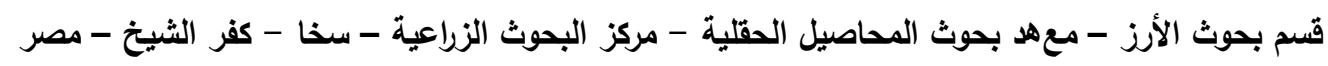

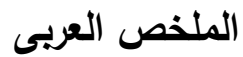

أجريت تجرية حقن في المزرعة البحثية لمحطة بحوث سخا الزراعية، كفر الثيخ، مصر خلال موسمي 2020 و و

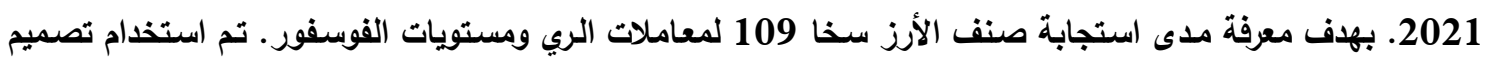

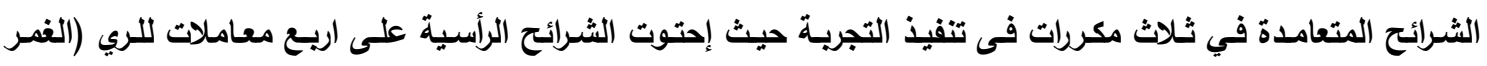

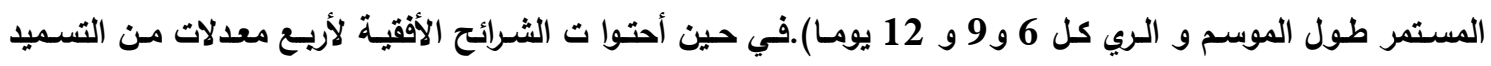

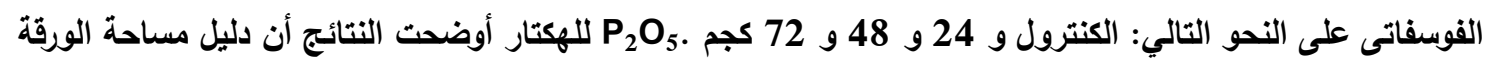

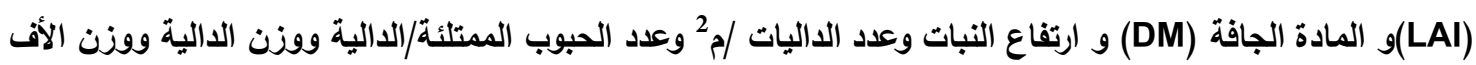

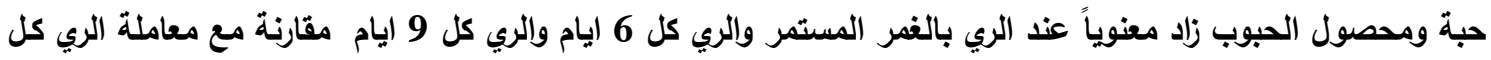

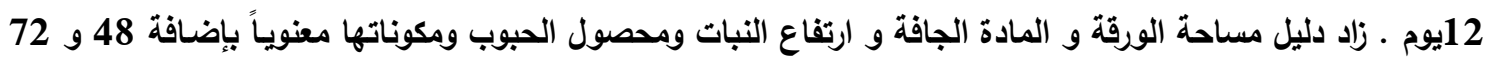

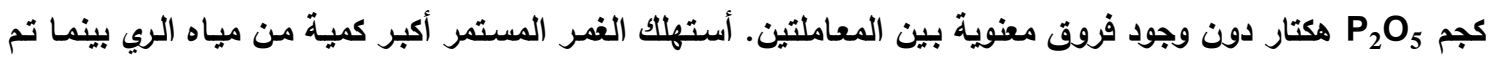

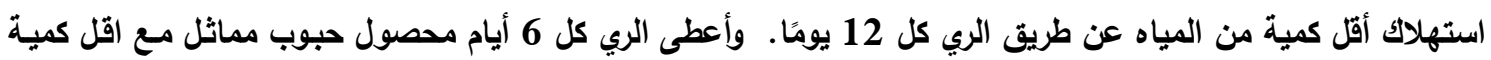

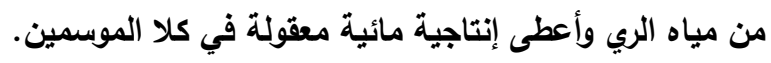

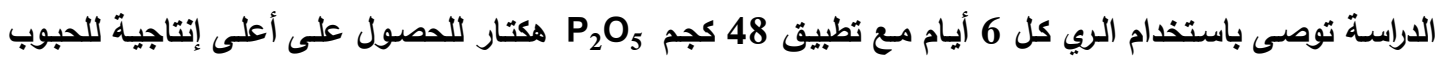
لصنف الأز سخا 109 وأفضل إنتاجية للمياه. 